Bull. Fac. Agric. Cairo Univ. 60: 226-233 (2009)

\title{
RESPONSE OF CORN YIELD TO WATER DEFICIT AND RICE STRAW MULCH AT SOME GROWTH STAGES
}

(Received: 12.1.2009)

\author{
By \\ M. A. El-Nady and T.I. Borham \\ Department of Soil Science, Faculty of Agriculture, Cairo University, Giza, Egypt.
}

\begin{abstract}
A field experiment was conducted at the Agricultural Experiments and Researches Station, Faculty of Agriculture, Cairo University, Giza, Egypt, during 2008 season. The study aimed to investigate the effect of skipping irrigation water at some corn growth stages with the application of surface cover on grain yield, some yield attributes and water use efficiency. Five irrigation treatments were applied, viz. control treatment $\left(T_{1}\right)$, skipping irrigation at, the vegetative stage $\left(T_{2}\right)$, grain filling stage $\left(T_{3}\right)$, during both vegetative and grain filling stages $\left(\mathrm{T}_{4}\right)$ and after every irrigation event throughout the crop growth period $\left(\mathrm{T}_{5}\right)$. Results showed that skipping irrigation was combined with a reduction in yield components and yield. The highest and lowest reductions in the yield were recorded with $\mathrm{T}_{5}$ and $\mathrm{T}_{2}$, respectively compared to $T_{1}$. Water deficit during vegetative stage had little effect on yield components and grain yield of corn. Mulched soil increased corn yield and its components compared with un-mulched one. Seasonal water evapotranspiration (ETa) was affected by skipping irrigation. The control $\left(\mathrm{T}_{1}\right)$, recorded the highest (ETa) value while, $\left(\mathrm{T}_{5}\right)$ recorded the lowest one. Mulching reduced (ETa) and increased water use efficiency (WUE). The highest (WUE) was achieved with $\left(\mathrm{T}_{2}\right)$ followed by $\left(\mathrm{T}_{4}\right)$ and $\left(\mathrm{T}_{5}\right)$, under un-mulched and mulched soil, compared with $\left(\mathrm{T}_{1}\right)$. Mulch enhanced the (WUE) as compared to the un-mulched one at all studied growth stages.
\end{abstract}

Key words: corn (maize) yield, rice straw mulch, skipping irrigation, water use efficiency (WUE).

\section{INTRODUCTION}

One of the important issues in the agriculture sector is how to save irrigation water and increase water use efficiencies in order to cultivate more areas. Since the agriculture sector is the major water user, new techniques and practices are needed to achieve water save. Skipping irrigation is one of such practices which can be used to save irrigation water by subjecting crops to a period of moisture stress with minimal effects on yield. Majumdar (2002) reported that the interval between two irrigations should be as wide as possible to save irrigation water without any adverse effect on the growth and yield. Also, Irmak et al. (2000) stated that eliminating unnecessary irrigations might improve corn production economics. Martin et al. (1984) pointed out that different irrigation strategies, soils and irrigation systems would require different amounts of irrigation to produce maximum yields. Irrigation schedules can be classified as full and deficit irrigation based on plant, soil, and climate conditions, Martin et al. (1990). Claassen and Shaw (1970), Mallett and De Jager (1971) showed that moisture stress occurring at various vegetative and reproductive stages of growth and development of a corn plant may reduce final grain yield, and that the extent of grain yield reduction depends not only on the severity of the stress but also on the stage of plant development when the stress occurs. Otegui et al. (1995) and Pandey et al. (2000) found that maize is particularly sensitive to water and other environmental stresses around flowering.

Musick and Dusek (1980) found that stress during grain filling was more harmful than stress during vegetative growth. Eck (1984) found that 14 and 28 days of stress during the vegetative stage of corn reduced its yield by about 23 and $46 \%$, respectively. Frey (1982) proposed that the most critical period for yield determination in the life cycle of corn begins approximately 2 weeks before silking and continues until 2 for 3 weeks after silking. Major stress before silking may cause failure in ear development, while stress after pollination results in limitation of kernel numbers or kernel abortion, Tollenaar (1977).

Zwart and Bastiaanssen (2004) reported that 
increases in water use efficiency can be achieved by different strategies. One of these strategies is to change crops capable of producing acceptable yields under deficit irrigation. Deficit irrigation provides a means of reducing water consumption while minimizing adverse effects on yield. The basic information needed to adopt this technique is the response of water deficit for various stages of the crops, Mao et al. (2003), Panda et al. (2003) and Zhang et al. (2004). Lamm et al. (1995) found that evapotranspiration demand by corn varies during its life cycle. To increase the water use efficiency of maize crop before implementing a deficit irrigation programme, it is necessary to know crop yield responses to water stress, either during defined growth stages or throughout the whole season, Kirda et al. (1999).

The objective of this study was to evaluate the effect of skipping irrigation at some growth stages of corn, on yield, some yield attributes and water use efficiency under surface cover (rice straw mulch) and without it.

\section{MATERIALS AND METHODS}

A field experiment was carried out at the Experiments and Researches Station, Faculty of Agriculture, Cairo University during the summer season of 2008.

The experiment was laid out in a randomized Complete Blocks Design with 3 replicates. Plot area was $70 \mathrm{~m}^{2}(3.5 \times 20.0 \mathrm{~m})$. Corn (hybrid Giza 122) grains were planted on June the $4^{\text {th }}$. Distances between rows and hills were 70 and $30 \mathrm{~cm}$, respectively. Agricultural practices including NPK application were done as recommended by the Ministry of Agriculture (2005). Some soil properties of the experimental site were measured and presented in Table (1). Field capacity, permanent wilting point, bulk density and particle size distribution, were determined according to Klute (1986).The electrical conductivity of the soil and the $\mathrm{pH}$ in the saturated soil paste were measured according to Page et al. (1982).

\subsection{Experimental treatments description}

Five irrigation treatments were applied, the control of 12-day irrigation intervals $\left(\mathrm{T}_{1}\right)$, the skipping irrigation treatments were, during vegetative stage $\left(T_{2}\right)$, grain filling stage $\left(T_{3}\right)$, both vegetative and grain filling stages $\left(\mathrm{T}_{4}\right)$ and after every irrigation event $\left(T_{5}\right)$. All plots were irrigated 20 days after planting, then watering was followed the skipping schedule as previously mentioned. Rice straw mulch was imposed 20 days after sowing.

\subsection{Soil moisture content}

In order to assess the changes in soil moisture status, soil samples were taken just before and 48 hours after each irrigation with auger at the soil depth intervals of 0-15, 15-30, $30-45$ and $45-60 \mathrm{~cm}$ from each plot. Soil moisture content was measured by gravimetric method (oven dry basis).

\subsection{Water relation}

\subsubsection{Actual water evapotranspiration (ETa)}

Water evapotranspiration was calculated according to the following equation by Hansen et al. (1979):

$$
E T a=\sum_{i=1}^{i=4} D_{i} * D_{b i} \frac{\theta_{2}-\theta_{1}}{100}
$$

Where:

$\mathrm{ETa}=$ Evapotranspiration $(\mathrm{cm})$ in the effective root zone $(60 \mathrm{~cm})$.

$\mathrm{D}_{\mathrm{i}}=$ Soil layer depth $(15 \mathrm{~cm})$.

$\mathrm{D}_{\mathrm{bi}}=$ Soil bulk density, $\left(\mathrm{g} . \mathrm{cm}-{ }^{3}\right)$ for this depth.

$\Theta_{1}=$ Soil moisture content $\%$ before irrigation (by weight).

$\Theta_{2}=$ Moisture content $\%, 48$ hours after irrigation (by weight).

I = Number of soil layers $(15 \mathrm{~cm})$.

\subsubsection{Water use efficiency (WUE)}

Water use efficiency was calculated according to Jensen (1983):

$$
\text { WUE = Y / ETa }
$$

Where:

$\mathrm{Y}=$ Seed yield in $\mathrm{kg} / \mathrm{fed}$.

$\mathrm{ETa}=$ Seasonal water evapotranspiration in $\mathrm{cm}$.

\subsubsection{Yield response factor $\left(k_{y}\right)$}

The water use-yield relationship was determined using the model of Stewart et al. (1975):

Where:

$$
1-\left(\mathrm{y}_{\mathrm{a}} / \mathrm{y}_{\mathrm{m}}\right)=\mathrm{k}_{\mathrm{y}} 1-\left(\mathrm{ET}_{\mathrm{a}} / \mathrm{ET}_{\mathrm{m}}\right) \text {, }
$$

$\mathrm{y}_{\mathrm{a}}=$ The actual yield (ton/fed.).

$\mathrm{y}_{\mathrm{m}}=$ The maximum yield ( ton/fed.).

$1-\left(\mathrm{y}_{\mathrm{a}} / \mathrm{y}_{\mathrm{m}}\right)=$ The decrease in relative yield.

$\mathrm{k}_{\mathrm{y}}=$ The yield response factor.

$\mathrm{ETa}=$ The actual evapotranspiration $(\mathrm{cm})$.

$\mathrm{ETm}=$ The maximum evapotranspiration $(\mathrm{cm})$.

$1-\left(\mathrm{ET}_{\mathrm{a}} / \mathrm{ET}_{\mathrm{m}}\right)=$ The decrease in relative evapotranspiration.

\subsection{Studied traits}

At harvest, on the $30^{\text {th }}$ of September six traits were studied. Ten guarded plants were 
randomly taken from the center of each plot, for measuring the following five traits:-

1- Ear weight (gm).

2-Ear length $(\mathrm{cm})$.

3-No.of rows/ear.

4-No.of grains/row.

5-The 100-grain weight (gm).

6- Grain yield/feddan (ton), was estimated from three rows in each plot. Corn grain yield was adjusted to $15.5 \%$ moisture content then grain yield/fed. was calculated.

\subsection{Statistical analysis}

All data were statistically analyzed following the procedure outlined by Snedecor and Cochran (1980) using "COSTAT program. The differences between mean values were compared according to multiple F-test and Duncan's Multiple Range Test (L.S.D) at 0.05 level of significance.

\section{RESULTS AND DISCUSSION 3.1. Effect of irrigation skipping on yield contributors}

Table (2) represents the means of ear weight $(\mathrm{gm})$, ear length $(\mathrm{cm})$, number of rows per ear, number of grains per row and 100-grain weight (gm), under mulched and un-mulched soil. Data show that skipping irrigation significantly affected all components of corn yield. The highest and lowest values of the studied components of corn are obtained with $\left(\mathrm{T}_{1}\right)$ and $\left(\mathrm{T}_{5}\right)$, respectively. When comparing $\left(\mathrm{T}_{1}\right)$ with $\left(\mathrm{T}_{2}\right),\left(\mathrm{T}_{3}\right),\left(\mathrm{T}_{4}\right)$ and $\left(\mathrm{T}_{5}\right)$, ear weight was reduced by $9.10 \%, 28.71 \%$, $32.19 \%$ and $41.14 \%$, respectively. While, $100-$ grain weight was reduced by $6.39 \% 16.51 \%$ $20.63 \%$ and $25.26 \%$, respectively, under unmulched soil. The reduction under mulched soil for the same order which gave for ear weight under un-mulched soil were $7.11 \%, 25.70 \%$, $31.38 \%$ and $40.69 \%$, respectively. For 100 -grain weight the percentage reductions were $6.61 \%$, $11.45 \%, 16.16 \%$ and $24.42 \%$, respectively The data indicate that treatments which experienced deficits during grain filling stage and during both vegetative and grain filling stages recorded less ear weight and 100-grain weight than those treatments that experienced deficits during vegetative growth stage. Bajwa et al. (1987) indicated that water stress at different growth stages affect grain weight per ear to a greater or less degree depending on stage of growth. Wilson (1968) stated that stress during the vegetative growth stage is less critical than during grain filling stage. Skipping irrigation after every irrigation event $\left(T_{5}\right)$ enlarged the reduction percentage of ear weight and 100-grain weight with respects to the control $\left(\mathrm{T}_{1}\right)$. In both ear weight and 100-grain weight there was no significant difference between the control and skipping during the vegetative growth. However, the two treatments $\left(T_{1}\right.$ and $\left.T_{2}\right)$ were significantly different from the other treatments. The data also show that, ear length and number of rows per ear were reduced in $\left(T_{4}\right)$ and $\left(T_{5}\right)$ compared to the other treatments. A significant difference between the two treatments $\left(\mathrm{T}_{4}\right.$ and $\left.\mathrm{T}_{5}\right)$ and the other treatments was obtained. Pandey et al. (2000) found that water stress reduced kernel number and weight/ear. Moreover, the number of grains per row also declined from $\left(\mathrm{T}_{2}\right)$ to $\left(\mathrm{T}_{5}\right)$. Number of kernels per ear is a yield component that varies markedly with stress, Fischer and Palmer (1984). No significant difference between $\left(T_{1}\right)$ and $\left(T_{2}\right)$ was found in ear length, no. of rows per ear and no. of grains per row under un-mulched soil. However, under mulched soil a significant difference between $\left(T_{1}\right)$ and $\left(T_{2}\right)$ in no. of grains per row was found.

\subsection{Effect of irrigation skipping on grain yield}

The grain yield of the different irrigation treatments are presented in Table (3). Under unmulched soil, the control $\left(T_{1}\right)$ produced the highest grain yield, i.e. 3.923 ton/feddan. This increase was result of the higher yield components such as ear weight, number of grains per row and weight of 100-grains. The treatment that imposed skipping after every irrigation event $\left(\mathrm{T}_{5}\right)$ gave the lowest yield, i.e. 2.295 ton/feddan. Yield reduction in $\left(\mathrm{T}_{5}\right)$ was associated with a decrease in ear weight, grain number and weight. Among the other treatments, skipping irrigation at the vegetative growth period $\left(\mathrm{T}_{2}\right)$ gave the highest grain yield of 3.549 ton/feddan, followed by the treatment of skipping irrigation during grain filling period $\left(\mathrm{T}_{3}\right)$, i.e. 3.083 ton/feddan and by $\left(\mathrm{T}_{4}\right)$ of skipping during both the vegetative and grain filling stages, i.e. 2.663 ton/feddan. Fischer and Palme (1984) reported that corn is relatively tolerant to water stress in the vegetative stage, very sensitive during the silking and moderately sensitive during the grain filling stage. Treatments $\left(\mathrm{T}_{2}\right), \quad\left(\mathrm{T}_{3}\right), \quad\left(\mathrm{T}_{4}\right)$ and $\left(\mathrm{T}_{5}\right)$ under un-mulching reduced grain yield by $9.51 \%, 21.40 \%, 32.12 \%$ and $41.55 \%$, respectively compared to the control $\left(\mathrm{T}_{1}\right)$. NeSmith and Ritchie (1992) found a $21-40 \%$ grain yield reduction due to severe water stress at grain filling. Under mulched soil, the grain yield is arranged in a descending order from $\left(\mathrm{T}_{2}\right)$ to $\left(\mathrm{T}_{5}\right)$. Skipping irrigation caused a reduction in grain yield of $\left(\mathrm{T}_{2}\right),\left(\mathrm{T}_{3}\right),\left(\mathrm{T}_{4}\right)$ and $\left(\mathrm{T}_{5}\right)$ compared to the control $\left(\mathrm{T}_{1}\right)$ by $4.26 \%, 20.94 \%, 30.80 \%$, and 
Table (1): Physical and chemical properties of soil.

\begin{tabular}{|c|c|c|c|c|c|c|c|c|c|c|}
\hline $\begin{array}{c}\text { Soil } \\
\text { depth } \\
(\mathbf{c m})\end{array}$ & $\begin{array}{c}\text { Field } \\
\text { capacity } \\
(\text { vol \%) }\end{array}$ & $\begin{array}{c}\text { Wilting } \\
\text { point } \\
(\text { vol \%) }\end{array}$ & $\begin{array}{c}\text { Available } \\
\text { soil } \\
\text { moisture } \\
\text { capacity } \\
(\text { vol \%) }\end{array}$ & $\begin{array}{c}\text { Bulk } \\
\text { density } \\
\left(\mathbf{g . c m}^{-3}\right)\end{array}$ & $\mathbf{p H}$ & $\begin{array}{c}\text { EC } \\
\left(\mathbf{d S . m ^ { - 1 } )}\right.\end{array}$ & $\begin{array}{c}\text { Total } \\
\text { sand } \\
(\%)\end{array}$ & $\begin{array}{c}\text { Silt } \\
(\%)\end{array}$ & $\begin{array}{c}\text { Clay } \\
(\%)\end{array}$ & $\begin{array}{c}\text { Texture } \\
\text { class }\end{array}$ \\
\hline $0-15$ & 37.61 & 15.68 & 21.93 & 1.24 & 7.72 & 2.36 & 43.2 & 35.1 & 21.7 & Loamy \\
\hline $15-30$ & 36.41 & 16.57 & 19.84 & 1.27 & 7.65 & 2.17 & 51.7 & 23.1 & 25.2 & S.C.I \\
\hline $30-45$ & 33.26 & 13.81 & 19.45 & 1.31 & 7.84 & 1.82 & 58.6 & 22.2 & 19.2 & S.L \\
\hline $45-60$ & 32.27 & 13.17 & 19.10 & 1.41 & 7.91 & 1.75 & 62.8 & 20.7 & 16.5 & S.L \\
\hline
\end{tabular}

Table (2): Corn yield components of un-mulched and mulched soils as affected by irrigation skip scheduling.

\begin{tabular}{|c|c|c|c|c|c|}
\hline \multirow[b]{2}{*}{ Treatments } & \multicolumn{5}{|c|}{ Un-mulched soil } \\
\hline & $\begin{array}{c}\text { Ear weight } \\
\text { (gm) }\end{array}$ & $\begin{array}{l}\text { Ear length } \\
\text { (cm) }\end{array}$ & $\begin{array}{c}\text { No. of } \\
\text { rows/ear }\end{array}$ & $\begin{array}{c}\text { No. of } \\
\text { Grains/row }\end{array}$ & $\begin{array}{c}\text { 100-grain } \\
\text { weight (gm) }\end{array}$ \\
\hline $\mathbf{T}_{1}$ & 190.82 & 18.00 & 14.0 & 42.00 & 27.87 \\
\hline $\mathbf{T}_{2}$ & 173.47 & 18.50 & 14.0 & 38.33 & 26.09 \\
\hline $\mathbf{T}_{3}$ & 136.03 & 17.10 & 16.0 & 34.67 & 23.27 \\
\hline $\mathbf{T}_{4}$ & 129.40 & 14.20 & 12.0 & 30.33 & 22.12 \\
\hline $\mathbf{T}_{5}$ & 112.32 & 11.00 & 11.0 & 26.33 & 20.83 \\
\hline \multirow[t]{2}{*}{ L.S.D. 0.05 } & 17.25 & 1.50 & 0.94 & 3.93 & 3.45 \\
\hline & \multicolumn{5}{|c|}{ Mulched soil } \\
\hline $\mathbf{T}_{1}$ & 212.72 & 19.60 & 14.0 & 44.67 & 29.52 \\
\hline $\mathbf{T}_{2}$ & 197.59 & 18.70 & 14.0 & 41.00 & 27.57 \\
\hline $\mathbf{T}_{3}$ & 158.05 & 17.30 & 14.0 & 38.00 & 26.14 \\
\hline $\mathbf{T}_{4}$ & 145.97 & 16.21 & 15.0 & 37.33 & 24.75 \\
\hline $\mathbf{T}_{5}$ & 126.15 & 12.30 & 12.0 & 29.67 & 22.31 \\
\hline L.S.D. 0.05 & 16.15 & 1.83 & 0.47 & 2.57 & 2.63 \\
\hline
\end{tabular}

Table (3): Corn grain yield (ton/fed.) of un-mulched and mulched soils as affected by irrigation skip scheduling.

\begin{tabular}{|c|c|c|}
\hline Treatments & Un-mulched treatments & Mulched treatments \\
\hline $\mathbf{T}_{1}$ & $\mathbf{3 . 9 2 3}$ & $\mathbf{4 . 3 1 1}$ \\
\hline $\mathbf{T}_{\mathbf{2}}$ & $\mathbf{3 . 5 4 9}$ & $\mathbf{4 . 1 2 7}$ \\
\hline $\mathbf{T}_{3}$ & $\mathbf{3 . 0 8 3}$ & $\mathbf{3 . 4 0 8}$ \\
\hline $\mathbf{T}_{4}$ & $\mathbf{2 . 6 6 3}$ & $\mathbf{2 . 9 8 3}$ \\
\hline $\mathbf{T}_{\mathbf{5}}$ & $\mathbf{2 . 2 9 5}$ & $\mathbf{2 . 5 7 2}$ \\
\hline L.S.D. 0.05 & $\mathbf{0 . 4 2 7}$ & $\mathbf{0 . 2 4 3}$ \\
\hline
\end{tabular}




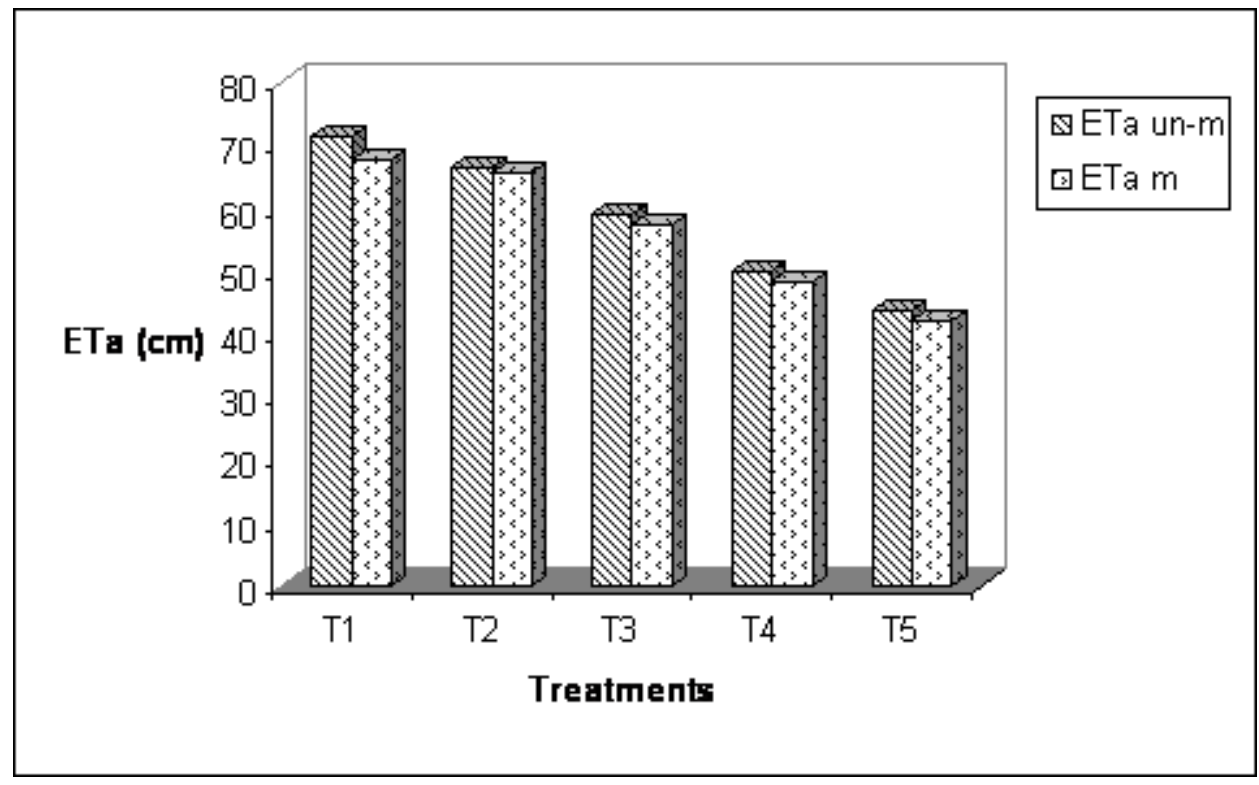

Fig. (1): Actual evapotranspiration (ETa) of un-mulched (un-m) and mulched (m) treatments.

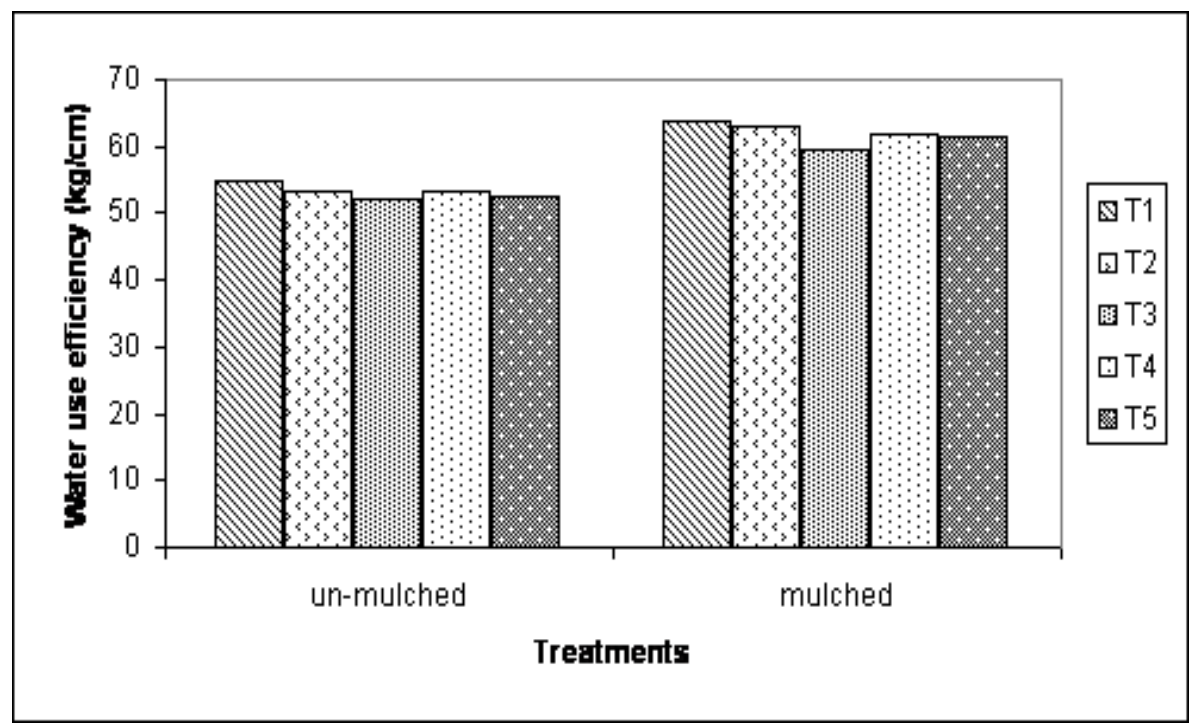

Fig. (2): Water use efficiency $(\mathrm{kg} / \mathrm{cm})$ of un-mulched and mulched corn. 
$40.32 \%$, respectively. The data also show that mulched treatments increased grain yield by $9.89 \%, 16.29 \%, 10.54 \%, 12.02 \%$ and $12.07 \%$ over the un-mulched treatments of $\left(\mathrm{T}_{1}\right),\left(\mathrm{T}_{2}\right),\left(\mathrm{T}_{3}\right)$, $\left(\mathrm{T}_{4}\right)$ and $\left(\mathrm{T}_{5}\right)$, respectively. The difference between the control and each of the other treatments are significant except irrigation skipping at vegetative stage $\left(\mathrm{T}_{2}\right)$. In general, the results indicate that corn could produce adequate yield when skipping irrigation is used during the vegetative stage which was less affected by skipping irrigation than the other growth stages. Moutonnet (2002) reported that timing the water deficit appropriately is a tool for scheduling irrigation for minimal yield reductions.

\subsection{Water relationships}

\subsubsection{Actual water evapotranspiration (ETa)}

Fig.(1) illustrates the actual evapotranspiration (ETa). The (ETa) values were varying from treatment to another. The variation in (ETa) values was due to the irrigation skipping scheduling at different growth periods and to the application of rice straw mulch. Maximum actual evapotranspiration (ETa) under both mulched and un-mulched conditions was obtained with the control $\left(\mathrm{T}_{1}\right)$ followed by $\left(\mathrm{T}_{2}\right),\left(\mathrm{T}_{3}\right),\left(\mathrm{T}_{4}\right)$ and $\left(\mathrm{T}_{5}\right)$, respectively. Mulched soil reduced (ETa) comparing with un-mulched soil.

\subsubsection{Water use efficiency (WUE)}

The calculated water use efficiency values for mulched and un-mulched corn at the different growth stages are shown in Fig.(2). Water use efficiency gave its highest value with $\left(\mathrm{T}_{1}\right)$ followed by $\left(\mathrm{T}_{2}\right),\left(\mathrm{T}_{4}\right),\left(\mathrm{T}_{5}\right)$ and $\left(\mathrm{T}_{3}\right)$ under both mulched and un-mulched corn. The good performance of treatment $\left(\mathrm{T}_{2}\right)$ was due to the relative increase in grain yield. The increase in (WUE) values of $\left(\mathrm{T}_{4}\right)$ and $\left(\mathrm{T}_{5}\right)$ over the control was due to the reduction in (ETa) and increased the (WUE) of these treatments. The presence of surface cover increased (WUE) for all treatments compared with those treatments without surface cover. Karam et al. (2003) reported that stressed plants have higher (WUE) values than wellwatered plants. This increase in efficiency is due to a large decline in plant transpiration because of reduced green leaf area as a consequence of water stress, which probably also reduced the evaporation from the dry soil.

\subsubsection{Yield response factor $\left(k_{\mathrm{y}}\right)$}

Yield response factor $\left(\mathrm{k}_{\mathrm{y}}\right)$ is defined as the decrease in relative yield with respect to the decrease in relative water evapotranspiration (ET),
Doorenbos and Kassam (1979). The crop yield response factor gives an indication of whether the crop is tolerant to water stress. A response factor greater than the unit indicates that, the expected relative yield decrease for a given evapotranspiration deficit is proportionately greater than the relative decrease in evapotranspiration, Kirda et al. (1999). The $\left(\mathrm{k}_{\mathrm{y}}\right)$ calculated for $\left(\mathrm{T}_{2}\right),\left(\mathrm{T}_{3}\right),\left(\mathrm{T}_{4}\right)$ and $\left(\mathrm{T}_{5}\right)$ were 1.38 , $1.27,1.07$ and 1.08 , respectively under unmulched soil and 1.48, 1.39, 1.08 and 1.07, under mulched soil, respectively. The obtained data show that, $\left(\mathrm{k}_{\mathrm{y}}\right)$ for all treatments was greater than the unit therefore, the relative decrease in yield was greater than the relative decrease in evapotranspiration. Among treatments, $\left(\mathrm{k}_{\mathrm{y}}\right)$ showed that the relative yield decreases is more important than the relative decrease in (ET) for $\left(T_{2}\right)$ followed by $\left(T_{3}\right)$ while, the relative decrease in (ET) is gradually becoming more important in $\left(\mathrm{T}_{4}\right)$ and $\left(\mathrm{T}_{5}\right)$ under un-mulched and mulched corn.

\section{Conclusion}

The grain yield of corn varied according to skipping irrigation schedule. The reduction in grain yield was depending on the growth stage at which moisture stress occurs. The losses in grain yield and yield components in skipping treatments during vegetative growth stage $\left(T_{2}\right)$ were less than the other ones. No significant difference between the control and $\left(T_{2}\right)$ treatment was found. Skipping irrigation during grain filling stage $\left(T_{3}\right)$ was found to be most vulnerable to irrigation deficit than during the vegetative stage $\left(\mathrm{T}_{2}\right)$. Although $\left(\mathrm{T}_{4}\right)$ and $\left(\mathrm{T}_{5}\right)$ did not increase the yield but they resulted in an increase in water use efficiency compared to $\left(\mathrm{T}_{3}\right)$. It may be concluded that skipping irrigation can be practiced during the vegetative stage for higher crop or during both vegetative and grain filling stages for higher water use efficiency with relative reduction in grain yield.

\section{REFERENCES}

Bajwa M.S., Akhtar A., Hussain M.R. and Raja M.B. (1987). Effect of irrigation frequencies and nitrogen rates on the protein contents of maize. Pakist. J.Agric.Res.8:325-329.

Classen M.M. and Shaw R.H. (1970). water deficit effects on corn.11. Grain components. Agron.J. 62:652-655. 
Doorenbos J. and Kassam A.H. (1979). Yield response to water. FAO irrigation and drainage paper No:33, Rome.Italy.

Eck H.V. (1984). Irrigated corn yield response to nitrogen and water. Agron. J. 76:421-428.

Fischer K.S. and Palmer F.E.(1984). Tropical maize. In: Golds Worthy, P.R. and Fischer, N.M.(Eds.),The physiology of Tropical Field Crops. Wiley New York, p.213-248.

Frey N.M. (1982). Dry matter accumulation in kernels of maize. Crop Sci. 21: 118-122.

Hansen V. W., Israelsen D. W. and Stringharm Q. E. (1979). Irrigation Principle and Practices, $4^{\text {th }}$ ed. John Wiley and Sons. New York.

Irmak S., Haman D.Z. and Bastug R. (2000). Determination of crop water stress index for irrigation timing and yield estimation of corn. Agron.J.92, 1221-1227.

Jensen M.E.(1983).Design and Operation of farm irrigations systems. Amer. Soc. Agric. Eng. Michigan, U.S.A.

Karam F., Breidy J. Stephan C. and Rouphael J. (2003). Evapotraspiration, yield and water use efficiency of drip irrigated corn in the Bekaa valley of Lebanon. Agric. Water Manage. 63(2): 125-137.

Kirda C. and Kanber R. (1999 a). Water, no longer a plentiful resource, should be used sparingly in irrigated agriculture. In: Kirda, C., Moutonnet, P., Hera,C. and Nielsen, D.R., eds. Crop Yield Response to Deficit irrigation, Dordrecht, The Netherlands, Kluwer Academic Publishers.

Kirda C., Kanber R. and Tulucu K. (1999 b).Yield response of cotton, maize, soybean, sugar beet, sunflower and wheat to deficit irrigation. In: Kirda C., Moutonnet P. Hera C. and Nielsen D.R., eds. Crop yield response to deficit irrigation, Dordrecht, The Netherlands, Kluwer Academic Publishers.

Klute A. (1986). Water retention: Laboratory Methods p.635-662. Methods of soil Analysis, Part $1,2^{\text {nd }}$ ed., ASA and SSSA, Madison.Wisconsin, U.S.A.

Lamm F. R., Spurgeon W. E. Rogers D. H. and Manges H. L. (1995). Corn production using subsurface drip irrigation. In Proceedings of The Fifth International Micro Irrigation Congress, Orlando, Florida, April 2-6. ASAE, st Joseph, Mich, U.S.A, p. 388-394.

Majumdar D.K. (2002). Irrigation water Management, Principles and Practice.
Prentice - Hall of India Privet Limited, New Delhi, India, P. 261-283.

Mallett J. B. and De Jager J. M. (1971). Effect of a moisture stress day upon maize performance. Agroplantae 3: 15-20.

Mao X., Liu M. Wang X. Liu C. Hou Z. and Shi J. (2003). Effects of deficit irrigation on yield and water use of greenhouse grown cucumber in the North China Plain. Agric. Water Manage. 61: 219-228.

Martin D. L., Stegman E. C. and Fereres E. (1990). Irrigation Scheduling Principles. In: Hoffman G. J., Howell T. A. and Soloman K. H. (Eds.), Management of Farm Irrigation Systems. ASAE, St. Joseph, MI, p. 155-203.

Martin D. L., Watt D. G. and Gilly J. R. (1984). Model and production for irrigation management. J. Irrigat. Drain. Eng. 110 (2): 149-164.

Ministry of Agriculture, Egypt (MOALR) (2005). cultivation of maize in the old lands. The central Administration for the Agricultural Extension. Bulletin No .961.

Moutonnet P. (2002). Yield response factors of field crops to deficit irrigation.p.11-16. In Deficit Irrigation Practices. Water Rep.22. FAo, Rome.

Musick J. T. and Dusek D. A. (1980). Irrigated corn yield response to water. Trans. Am. Soc. Agric. Eng. 23:92-98.

NeSmith D. S., and Ritchie J. T. (1992). Maize (Zea mays L.) response to a severe soil water deficit during grain filling. Field Crops Res.29:23-35.

Otegui M. E., Andrade F. H. and Suero E. E. (1995). Growth, water use, and kernel abortion of maize subjected to drought at silking. Field Crops Res. 40: 87-94.

Page A.L., Miller R.H. and Keeney D.R.(Ed) (1982). Methods of Soil Analysis. Part-2 Chemical and Microbiological Properties $2^{\text {nd }}$ ed. Amer. Soc. of Agron. Madison, Wisconsin, U.S.A.

Panda R.K., Behera S. K. and Kashyap P.S. (2003). Effective management of irrigation water for wheat under stressed conditions. Agric. Water Manage. 63 (1): 37-56.

Pandey R.K., Maranville J. W. and Admou A. (2000). Deficit irrigation and nitrogen effects on maize in a sahelian environment. Grain yield and yield components. Agric. Water Manage.46 : 1-13. 
Snedecor G.W and Cochran W.G. (1980). Statistical Methods. $7^{\text {th }}$ Ed. Iowa State Univ. Press, Ames. Iowa, U.S.A. p: 593.

Stewart J.I. , Misra R.D. Pruitt W.O. and Hagan R.M.(1975).Irrigation corn and sorghum with a deficient water supply. Trans. ASAE 18:270-280.

Tollenaar M.(1977). Sink-source relationships during reproductive development in maize. A review. Maydica XXII: 49-75.

Wilson J.H. (1968). Water relations of maize. Part 1.Effects of severe soil moisture stress imposed at different stages of growth on grain yields of maize. ,Rhod. J.Agric.Res.6:103-105.

Zhang Y., Kendy E., Qiang Y., Changming L., Yanjun S. and Hongyong S.(2004). Effect of soil water deficit on evapotranspiration, crop yield, and water use efficiency in the North China Plain. Agric. Water Manage. 64: 107-122.

Zwart S.J. and Bastiaanssen W.G.M. (2004). Review of measured crop water productivity values for irrigated wheat, rice, cotton and maize. Agric. Water Manage. 69 (2): $115-133$.

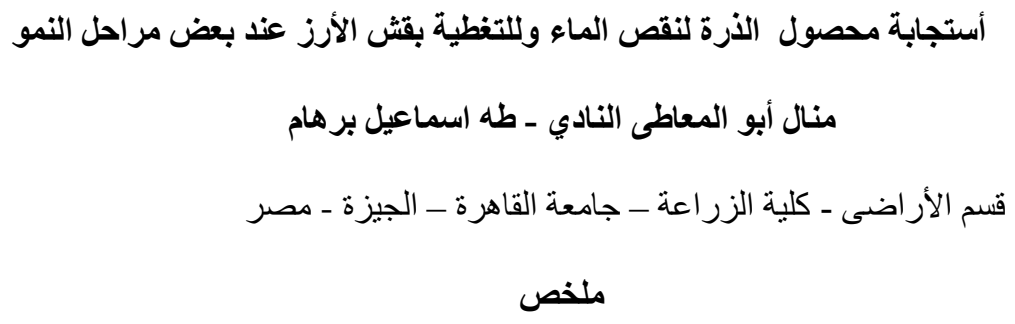

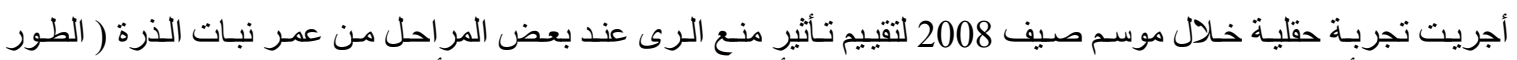
الخضرى(T2) - طور أمتلاء الحبوب (T)

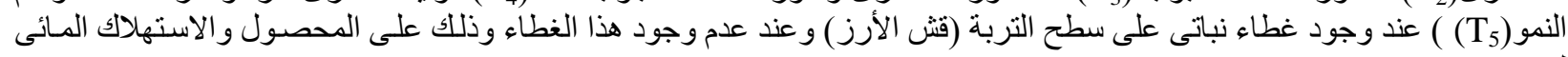

ويمكن تلخيص النتائج فى الآتى:

1- أدى تعريض نباتات الذرة للإجهاد الرطوبى نتيجة منع الرى خلال مر احل النمو تحت الدر اسـة إلى حدوث نقص في محصول

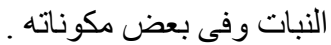

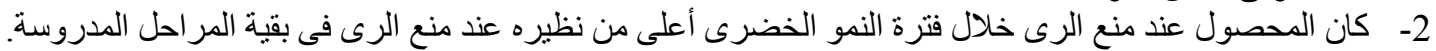

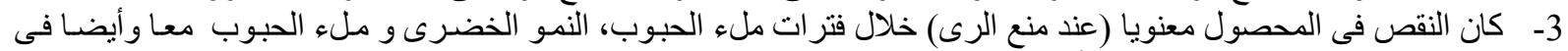

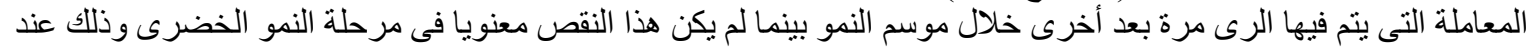

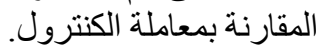

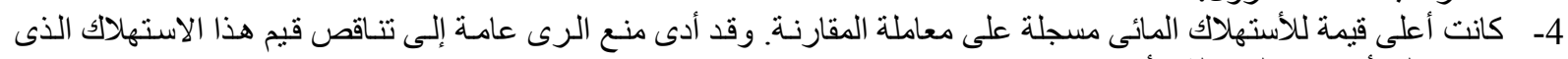

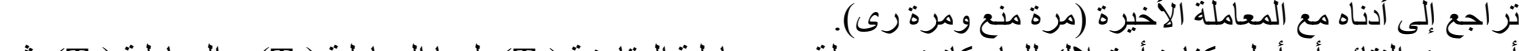

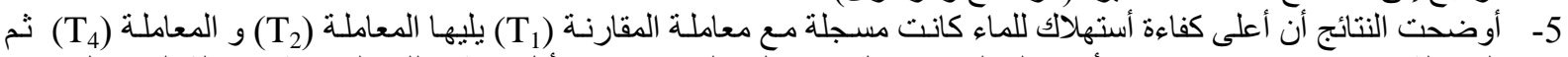

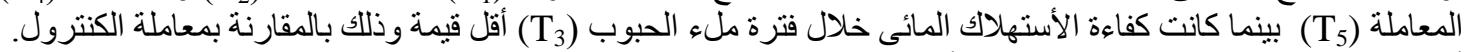

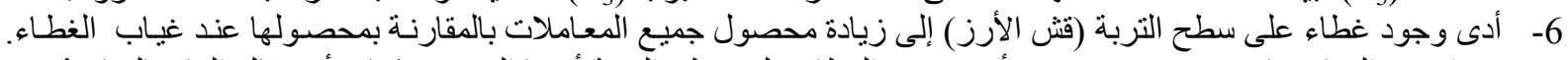

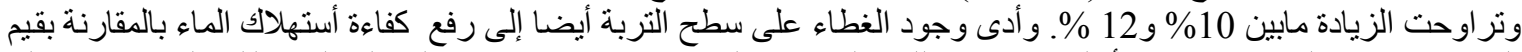

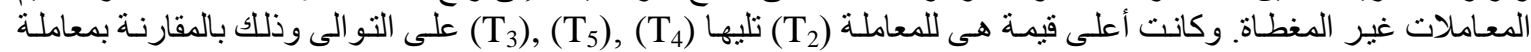

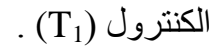
7- يمكن توفير مياه الرى و الحصول على أعلى كفاءة لاستهلاك المياه وذلك بجدولة الرى ليكون مرة بعد مرة خـلال فترة النـو

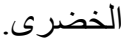

